\title{
Perceptions of the Student Teaching Triad: An Inquiry into Relationships and Supervision 探討實習教學與视學的關係
}

\author{
Kelle L. MURPHY \\ School of Education, \\ University of Guam, GUAM
}

艾尼梅菲

關島大學教育學院

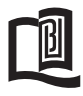

\begin{abstract}
The study was designed to examine the perceptions of relationships formed among members of the student teaching triad and to examine the perceptions of supervision of student teachers given by cooperating teachers and college supervisors. Participants $(\mathrm{N}=24)$ included eight student teaching triads. The study was conducted over a 14-week student teaching experience. In-depth interviews and daily journals were employed as methods of data collection. It was found that training was not received by cooperating teachers and college supervisors and was based on experience. The coalition was formed between the student teacher and cooperating teacher. Expectations of cooperating teachers were higher and based on a pragmatic view whereas expectations of college supervisors were based on theory.
\end{abstract}

Key Words: Teacher Education, Elementary, and Secondary

\section{摘 要 \\ 本文旨在探討實習教學與視學的關係, 邀請得24位實習生進行14周的實習教學, 初步結果顯示本科教師與大學講師對實習生 存有不同的見解。}

\section{Introduction}

The student teaching triad consists of the student teacher, the cooperating teacher, and the college supervisor (Veal \& Rikard, 1998). Relationships within a triad can be very complex and confusing. Once a third person is added to a dyad, communication has the potential to be misinterpreted and a power struggle among the three members can arise (Caplow, 1968). Often times, in relationships involving three members, a coalition is eventually formed between two members, resulting in the third member feeling left out (Veal \& Rikard, 1998). A majority of the time within the student teaching triad, the coalition will be formed between the student teacher and the cooperating teacher, because those two spend a great deal of time together on a daily basis (Veal \& Rikard,
1998). The coalition often remains between the student teacher and the cooperating teacher, due to the absence of the college supervisor (Veal \& Rikard, 1998). Many researchers agree that the cooperating teacher is the most important figure within the triad and is also viewed as the most important by the student teacher (Gallemore, 1981; Richardson-Koehler, 1988; Rikard \& Veal, 1996; Vogt, 1988).

Many student teachers, cooperating teachers, and college supervisors differ in their expectations of each of the roles of the triad members. Tensions and anxieties can emerge as a result of the constant shifting in roles, which can add strain to the relationships among the student teacher, the cooperating teacher, and the college supervisor (Veal \& Rikard, 1998). Lack of compatibility 
between the cooperating teacher and the student teacher appears to be the most prevalent problem reported by researchers (DelGesso \& Smith, 1993; Grimmett \& Ratzlaff, 1986; Koerner, 1992; Vogt, 1988). Compatibility adds to the professional and maturational growth of the student teacher (DelGesso \& Smith, 1993). Vogt (1988) found that a more successful experience is likely to occur when common philosophies exist between the cooperating teacher and the student teacher. Many researchers (Koerner, 1992; Zeichner 1992) found that often times the student is placed in a setting based on convenience, location, and availability. Little consideration may be given to the degree of compatibility between the cooperating teacher and the student teacher, or which placement would offer the best learning experience for the student.

Lack of clear guidelines given to the cooperating teacher regarding supervision and expectations of the student teacher was a dominant area of concern found by many researchers (Grimmett \& Ratzlaff, 1986; Koerner, 1992; Richardson-Koehler, 1988; Rikard \& Veal, 1996). Grimmett and Ratzlaff (1986) found "that the role of the cooperating teacher is poorly defined and that teachers generally are unprepared for the task of student teaching supervision" (p. 42). Supervision by the cooperating teacher is guided by past personal experiences in student teaching and current professional practices (Koerner, 1992; Richardson-Koehler, 1988; Rikard \& Veal, 1996). Preferred supervisory style varies among many cooperating teachers. Preference of styles was developed through experience and what was used for them as student teachers (Koerner, 1992). With a lack of training and guidelines on sufficient supervision, most cooperating teachers adapted and modified the most effective style in an effort to assist the student teacher (Rikard \& Veal, 1996).

Because cooperating teachers are not given clear guidelines on how to supervise student teachers (Grimmett \& Ratzlaff, 1986; Koerner, 1992; Richardson-Koehler, 1988; Rikard \& Veal, 1996), perceptions of the student teacher's achievement by the cooperating teacher can often clash with the perspectives of the college supervisor (Gallemore, 1981). Gallemore (1981) and Moon, Niemeyer, and Simmons (1988) found that there was the difference in perceptions of achievement by the student teacher, the cooperating teacher, and the college supervisor as well as the variations in meaning attached to constructive criticism given to the student teacher. Often, the cooperating teacher and college supervisor will view achievement in a teaching episode higher than the student teacher (Gallemore, 1981). Gallemore (1981) and Veal and Rikard (1998) found that more similarities in perceptions and personal views occurred between the cooperating teacher and the student teacher.

The purpose of this study was to examine the perceptions of relationships formed among members of the student teaching triad and to examine the perceptions of supervision of student teachers given by cooperating teachers and college supervisors. The following research questions were examined within the context of the current study: (a) What are the perceptions of relationships formed among student teachers, cooperating teachers, and college supervisors? and (b)What are the perceptions of supervision given to student teachers by cooperating teachers and college supervisors?

\section{Method}

\section{Participants}

Participants in this study included a convenience sample of eight student teaching triads (8 student teachers, 8 cooperating teachers, and 8 college supervisors). All participants were recruited from the same educator licensure program from a private college in the Northeast. The study was conducted over a 14-week practicum experience in student teaching. The first 7 weeks consisted of 3 student teachers at elementary placements, 3 assigned cooperating teachers, and 3 assigned college supervisors. The second 7 weeks consisted of 5 student teachers at secondary placements (2 middle schools and 3 high schools), 5 cooperating teachers, and 5 college supervisors. The student teaching experience was the final requirement prior to eligibility for licensure. None of the student teachers were assigned to the same cooperating teacher or college supervisor.

Student teachers consisted of 4 female and 3 male undergraduate students and 1 female graduate student. In addition to teaching requirements throughout the licensure program, the majority of student teachers also had experience teaching in various sports camps. Only 1 student teacher had previous teacher certification in a core subject. 
Cooperating teachers consisted of 5 female and 3 male supervisors. Public school teaching experience for cooperating teachers ranged from 7 years to over 31 years $(\underline{\mathrm{M}}$ $=18.38 ; \underline{\mathrm{SD}}=9.61$ ). Experience supervising student teachers for cooperating teachers ranged from 4 years to 25 years $(\underline{\mathrm{M}}=11.13 ; \underline{\mathrm{SD}}=8.04)$. College supervisors consisted of 4 female and 4 male supervisors. Of the college supervisors, 3 male and 1 female were retired physical educators serving as part-time adjunct professors supervising student teachers in the current licensure program. Public school teaching experience for the 4 adjunct faculty ranged from 20 years to 34 years $(\underline{\mathrm{M}}=$ 26.75; $\underline{\mathrm{SD}}=5.74)$. Experience supervising student teachers for the 4 adjunct faculty was 2 years. Public school teaching experience for the 4 full-time college supervisors ranged from 3 years to 21 years $(\underline{\mathrm{M}}=13.00 ; \underline{\mathrm{SD}}=7.62$ ). Experience supervising student teachers for the 4 fulltime college supervisors ranged from 2 years to 16 years $(\underline{\mathrm{M}}=8.25 ; \underline{\mathrm{SD}}=6.13)$. All of the college supervisors had served as cooperating teachers while teaching in the public schools. Five of the college supervisors had additional administrative experiences that ranged from Director of Athletics, Director of Physical Education, and Assistant Principal.

All cooperating teachers and college supervisors were either alumni or currently teaching courses in the educator licensure program at the same college as the student teachers. Also, they all had supervised student teachers for a minimum of 2 years and were familiar with the requirements of the program. Procedures and expectations were explained and informed consent was signed by all participants prior to the study.

\section{Data Collection}

\section{In-depth Interviews}

In-depth interviews as described by Seidman (1998) were used in the current study as the primary method of data collection. Each member of the eight student teaching triads participated in a total of three telephone interviews during the 7-week elementary or 7-week secondary placement. Telephone interviews were conducted by the researcher and were used due to the geographical distance between the researcher and participants. The first interview occurred within the first or second week. The second interview occurred within the third or fourth week and the third interview occurred within the sixth or seventh week of the placement. The telephone interviews were transcribed verbatim and emailed to the participants for member checking prior to each subsequent interview. In addition, two peer debriefers met with the researcher periodically and reviewed the transcribed notes and added professional insight. The first peer debriefer was a Professor of Physical Education and the second peer debriefer was an Assistant Professor of Sociology who specialized in application and interpretation of sociological theory. Each peer debriefer was selected according to area of expertise.

A pilot study was used to determine an adequate length of time for the interviews along with face validity of each question. A total of 3 participants who did not take part in the current study participated in the pilot study. Each participant represented a role of the student teaching triad (1 student teacher, 1 cooperating teacher, and 1 college supervisor). Interview questions are presented in Appendix A.

\section{Appendix A. INTERVIEW \# 1- STUDENT TEACHER}

For student teachers, the first interview was used to gather background information.

1. While a student in high school, did you have any positive experiences that led you to choose the field of teaching?

2. Describe these experiences.

3. What type of teaching or coaching experience have you had?

4. Are you looking forward to this upcoming student teaching experience?

5. Describe or expand.

\section{INTERVIEW \# 1-COOPERATING TEACHER/COLLEGE SUPERVISOR}

1. Typically, during an academic year, how many student teachers do you supervise?

2. What type of training did you receive prior to supervising student teachers? 


\section{INTERVIEW \# 2-STUDENT TEACHER}

1. Lets talk about your experience at this site. Describe your relationship with the cooperating teacher.

2. Describe what you like about the relationship with this cooperating teacher.

3. How is this relationship different from relationships with previous cooperating teachers at various sites (methods classes or prepracticum)?

4. Describe the differences in supervisory styles among the cooperating teacher at this site to previous cooperating teacher at various sites (methods classes or prepracticum).

5. Describe your relationship with the college supervisor.

6. Describe what you like about the relationship with this college supervisor.

7. Compare and contrast your relationship with both the cooperating teacher and the college supervisor at this site.

8. Do you feel that each have similar expectations of you as a student teacher?

9. Describe similarities or differences.

\section{INTERVIEW \# 2-COOPERATING TEACHER/COLLEGE SUPERVISOR}

1. Describe your relationship with this particular student teacher.

2. Is this relationship with this student teacher typical of relationships you have had supervising prior student teachers?

3. Describe how it is similar or different.

4. Are your expectations of teaching for this student teacher similar to the expectations of the college supervisor/cooperating teacher?

5. Describe the similarities or differences.

6. Do you feel that you both agree on similar issues of teaching regarding this student teacher?

7. In what areas does there seem to be conflict (if applicable)?

8. Describe your relationship with the college supervisor/cooperating teacher assigned to this student teacher. INTERVIEW \# 3-STUDENT TEACHER

1. Overall, was your experience with the cooperating teacher positive or negative?

2. Describe your experience.

3. Overall, was your experience with the college supervisor positive or negative?

4. Describe your experience.

5. Did you find it helpful or more difficult to have two supervisors at each site (cooperating teacher and college supervisor)?

\section{INTERVIEW \# 3-COOPERATING TEACHER/COLLEGE SUPERVISOR}

1. Describe your overall feelings of supervising this student teacher.

2. Highlight a significant experience you had with this student teacher and how it affected you as a supervisor.

3. Did anything change regarding how you will supervise student teachers in the future?

4. Describe what changed.

5. Describe a significant experience you had with the college supervisor/cooperating teacher assigned to this student teacher.

6. How has your relationship with this college supervisor/cooperating teacher changed or affected how you will approach future college supervisors/cooperating teacher assigned to student teachers?

7. Describe the experience of supervising a student teacher in conjunction with an additional supervisor (the college supervisor/cooperating teacher). 


\section{Daily Journals}

Daily journals were requirements of all student teachers in placement and were used as a secondary method of data collection. Guidelines for the journals included reflection on significant occurrences, problems encountered, possible solutions, effectiveness of solutions, experiences learned in teaching, emotional responses and reflections, and any questions or concerns that arose (Practicum in Physical Education Fieldwork Handbook). Student teachers emailed journals to the researcher either daily or at the completion of each week. The researcher reviewed the journal entries prior to each interview to supplement the interviews and gain additional insight into the thought processes of student teachers during a teaching episode. In addition, the two peer debriefers met with the researcher periodically and reviewed the journal entries and added professional insight.

\section{Data Analysis}

Data analysis of qualitative data followed the same process as Murphy (2007). Data analysis occurred simultaneously with data collection (Thomas, Nelson, \& Silverman, 2005). Data were analyzed inductively (Thomas et al., 2005). Three phases of coding (open, axial, and selective) described by Neuman (1991) were utilized to interpret transcribed interviews and daily journals. The purpose of each phase of coding was to reduce and condense data. A constant comparison method was also used (Glaser \& Strauss, 1967).

During open coding, data were combed to identify references to relationships and supervision, which related directly back to the research questions. Exact quotes by participants were copied onto color-coded post-its and treated as individual raw data units (Gould, Finch, \& Jackson, 1993). Each raw data unit was identified by the gender-neutral name assigned to the participant, the placement (elementary or secondary) and the role of the participant (student teacher [ST], cooperating teachers [CT], or college supervisor [CS]). Concept maps were developed at this point as a technique to visualize the connections among raw data units (Maxwell, 1996) and were created for each role (ST, CT, CS) and combined the placement (elementary and secondary). Post-its containing raw data units were placed on poster board to create the concept maps (Murphy, 2007).
During axial coding, raw data units were combed again several times, performing a constant comparison (Glaser \& Strauss, 1967) analysis and condensed into color-coded categories. Categories were general names containing one to three words given to the overall meanings of raw data units. Only raw data units with the exact meanings were placed under the same category. If raw data units had different meanings, new categories were formed (Murphy, 2007).

During selective coding, the categories were combed and condensed even further into color-coded themes that could be explained by existing pedagogical research. Themes also contained one to three words. Categories with exact concepts were condensed into the same theme. New themes were identified for categories with different concepts (Murphy, 2007).

\section{Trustworthiness}

Trustworthiness was provided in the current study by the following: (a) audit trail, by the use of written notes, transcribed notes, synthesis of data through concept maps, and process notes, and a pilot study (Lincoln \& Guba, 1985); (b) in-depth description of participants and the setting (c) triangulation, by the use of interviews and daily journals; (d) member checking by sending transcribed notes to all participants, along with beginning the second and third interviews with a review of the previous interview that highlighted and clarified any areas of concern obtained in the transcribed notes and daily journals and; (e) peer debriefers, in which two peer debriefers met with the researcher periodically and reviewed the transcribed notes and daily journals and added professional insight.; (f) purposeful selection of participants to fit criteria of study and maintaining anonymity and confidentially (Lincoln \& Guba, 1985).

\section{Results}

Participants were assigned a gender-neutral name to accurately preserve and reflect the voice of each. Results have been presented combining placement (elementary and secondary) and according to role (student teacher [ST], cooperating teachers [CT] and college supervisor [CS]. Theories have been presented with categories as subheadings. 
The analysis resulted in the following: for student teachers 168 raw data units were condensed into 7 categories and finally 3 themes; for cooperating teachers, 126 raw data units were condensed into 4 categories and finally 3 themes; for college supervisors, 142 raw data units were condensed into 5 categories and finally 4 themes. A summary of categories and themes combining placement and according to role are presented in Figure 1.

\section{Figure 1. Student Teachers}

\section{Categories}

Theory

Practical

Daily Contact

Feedback

Structure

Personal Connections

Informal

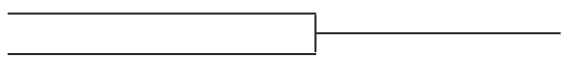

Cooperating Teachers

\section{Categories}

Personal Connections

New Ideas

Higher

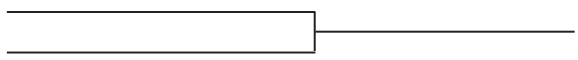

Enhancement

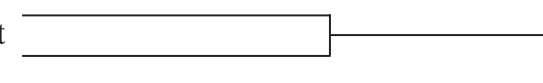

College Supervisors

\section{Categories}

Frequent Communications

Expectations

Complementary

Informal

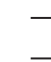

Enhancement

\section{Themes}

Expectations

Professional Growth

Communication

\section{Themes}

Professional Growth

Expectations

Supervisory Model

\section{Themes}

Modifications

Expectations

Communication

Supervisory Model 


\section{Student Teachers}

Student teachers were asked questions regarding their perceptions of overall relationships formed with cooperating teachers and college supervisors along with questions regarding their perceptions of supervision received by cooperating teachers and college supervisors. Categories and themes formed reflect areas conducive to professional development of student teachers.

\section{Expectations}

All student teachers agreed that the expectations received from cooperating teachers and college supervisors were different.

Theory. Student teachers stated that the expectations from college supervisors were higher, not always realistic given the teaching situation, and based on theory. In reference to receiving lesson ideas from the college supervisor who stressed standard-based teaching, Brook, Elementary ST, explained:

But that doesn't help me. I can know all I want about standards, but that doesn't help me teach in a class, you know what I mean? It helps me plan my lesson, but it doesn't help me teach, you know what I mean?

Expectations from college supervisors were perceived by student teachers to be based more on what was learned in the classroom.

Practical. Student teachers agreed that expectations of cooperating teachers were more realistic and based on a pragmatic view. Often times, methods that were taught to student teachers by cooperating teachers were methods that were based on what worked with the student population rather than what was learned in the college classroom. Aran, Elementary ST, explained the difference between what was learned in classroom and what the cooperating teacher was teaching by stating:

Well, that (methods class in college) was more focused on actually making me be a teacher .... now it's more, she's (cooperating teacher) trying to base it off of what goes on in the real world and how to adapt to that- like broadening your teaching skills.
In reference to prior planning for lessons Dayna, Secondary ST journaled: "He [cooperating teacher] doesn't really care too much about the lesson planning. He [cooperating teacher] feels if I can teach a lesson, you know, it doesn't really matter what is on paper." Emphasis from cooperating teacher was on the development of effective teaching skills and what worked in terms of practicality for the target population.

Daily contact. All student teachers stated that the difference in expectations between the college supervisor and cooperating teacher was due to the amount of contact. Regan, Secondary ST, expressed the overall sentiment of student teachers by stating:

Well, (name of cooperating teacher) and I see each other every day and (cooperating teacher) sees me you know where I started last week teaching and how I've even improved from this week. . . just (name of cooperating teacher) I think can see a huge difference because (cooperating teacher) sees me every day. (Cooperating teacher) sees me working on things were as (name of college supervisor see me three times.

College supervisors were not necessarily able to see the amount of change or improvement in performance of student teacher due to infrequent visits. Expectations of student teachers were based on what was observed by college supervisors.

\section{Professional Growth}

All student teachers placed an importance on developing close and personal relationships with cooperating teachers and college supervisors. Student teachers agreed that the critical elements of a successful relationships involved feedback, resources, structure, and personal connections.

Feedback. Student teachers expressed the desire to receive constructive criticism from cooperating teachers that assisted them to improve their teaching. Aran, Elementary ST, journaled: "She (cooperating teacher) is very good about providing feedback or providing information that could be useful to me." Regan, Secondary ST reiterated: "(Name of cooperating teacher) sits and watches me and you know, jots down notes and tells me what I need to work on, what's good, give me some ides of how I can fix things." 
Structure. Student teachers expressed the importance of structure and knowing exactly what was expected of them by cooperating teachers. In an explanation of the difference between the expectations of the cooperating teacher and the college supervisor, Jamie, Secondary ST, stated: “. . . I think (college supervisor's expectations) are very black and white and I think (cooperating teacher's expectations) are very gray." The student teacher further explained: "(name of college supervisor) is more firm on, you know, this is what I expect from you." Frustration and anxiety was less when expectations were clear.

Personal Connections. The success of the relationship for all student teachers was based on the personal connections that they were able to establish with cooperating teachers. Student teachers stated that due to the daily contact, closer relationships were formed with the cooperating teacher. Brooke, Elementary ST, stated:

We have a real good relationship, I mean, it's not just she is my cooperating teacher and I'm her student and whatever. ... I feel comfortable being able to you know take risks on whatever, and not have to worry about the grade I'm getting. So I just worry about, you know, learning more as a teacher."

Developing comfortable relationships allowed student teachers to relax and concentrate on learning from the experience. When personal connections were established, student teachers perceived that they were treated more as peers and colleagues rather than student teachers.

\section{Communication}

The dominant form of communication with college supervisors was through daily journals and emails. As a result, student teachers did not develop as close relationships with college supervisors and in some cases, did not feel as comfortable.

Informal. Student teachers agreed that the informal communication with college supervisors did not allow for close relationships to occur and as a result they did not really know their college supervisors other than through the journals and emails. Kendal, Elementary ST, explained: "You know, we know each other through the journals and stuff." Brooke, Elementary ST, expanded: "I mean, I email (name of college supervisor) every night and he emails me back, but I don't like talk about personal things in my journals." When student teachers had difficulties, the tendency was to turn to the cooperating teachers. Casey, Secondary ST, stated: "I email him (college supervisor) every day but, I feel more comfortable with (cooperating teacher) because I'm used to him." As a result, student teachers had the tendency to turn toward cooperating teachers for assistance.

\section{Cooperating Teachers}

Cooperating teachers were also asked questions regarding their perceptions of relationships formed with student teachers and college supervisors along with questions regarding their perceptions of supervision given to student teachers by cooperating teachers. Categories and themes formed reflect areas conducive to professional development and growth for cooperating teachers and student teachers.

Overall, specific formal training with regard to supervision of student teachers was not received by cooperating teachers in the current licensure program. Cooperating teachers stated that training was based on present teaching experience, ongoing communication with colleagues, attendance at professional seminars, experience as alumni, familiarity with the requirements of the current licensure program, and the Practicum in Physical Education Fieldwork Handbook that was given to all supervisors as a resource. Regarding prior training, Brook, Elementary CT, stated "I really didn't have any training. It was like here it is and there you go. So over the years, you know, you just kind of develop a way to deal with it you know?" The familiarity with the requirements of the current licensure program created a consistency in expectations that was demonstrated by all supervisors.

\section{Professional Growth}

Personal Connections. Similarly to the student teachers, cooperating teachers judged the success of the relationship based on the compatibility. Brooke, Elementary CT, explained "Yeah, you know, I try to make it a relaxed relationship and a personal relationship so that we can enjoy each other and have fun."

New Ideas. All cooperating teachers stated that student teachers brought new ideas which aided in their personal professional growth. Kendal, Elementary CT, stated: "It is very refreshing to have a new mind to work in tandem with. It brings out things that I didn't 
always think about." Professional growth was viewed not only in terms of the student teacher, but also for the cooperating teachers.

\section{Expectations}

Higher. Cooperating teachers agreed that their expectations of achievement of student teachers were higher than that of the college supervisors. This was due to the daily contact with the student teacher and the ability to realistically view achievement over time. Brooke, Elementary CT, expressed: "You know, I have higher expectations of (name of student teacher) teacher performance than you know maybe (name of college supervisor) would have because a supervisor only comes in a few times and I am here everyday." Due to years of experience in the particular setting, the cooperating teachers may have had a better understanding of the contextual factors that affected student learning. Familiarity with the program and school allowed cooperating teachers to more accurately gauge achievement of student teachers.

\section{Supervisory Model}

In terms of student teachers being supervised by two separate supervisors (cooperating teacher and college supervisor), cooperating teachers stated that it was a necessity and important for students to have two supervisors.

Enhancement. Cooperating teachers all agreed that the presence of two supervisors enhanced the experience for student teaches. Sean, Secondary CT, explained the importance of having one supervisor that represented the theory based knowledge taught in the classroom and one supervisor that represented the practical knowledge learned by the cooperating teacher. Sean, Secondary CT, explained:

I think it's important to have a college person there to ah make sure that a lot of the standards that the college is real with-the classroom standards- are being followed and then have me there to deal more with the practical experiences as far as the different things that (student teacher) applies that might work in the setting an might not.

Kendal, Elementary CT, agreed, stating: "Well, it's a necessary point because I'm not always right and there are a lot of times when I don't always have the answer, so it's always good to have a second person around." Cooperating teachers agreed that each supervisor had his or her own strengths that contributed to the overall growth and professional development of student teachers.

\section{College Supervisors}

College supervisors were asked questions regarding their perceptions of relationships formed with student teachers and cooperating teachers along with questions regarding their perceptions of supervision given to student teachers by college supervisors. Categories and themes formed reflect areas conducive to professional development and growth for college supervisors and student teachers.

Overall, college supervisors also agreed that specific formal training with regard to supervision of student teachers was not received by college supervisors in the current licensure program. Similarly to cooperating teachers, college supervisors stated that training was based on teaching experience, interactions with colleagues, attendance at conferences and professional development meetings, along with experience as alumni and familiarity with the requirements of the current licensure program.

\section{Modifications}

In response to what they would change in terms of their supervisory style, most college supervisors stated that increasing the communication with the cooperating teachers would be important along with clearly identifying expectations if difficulties had been experienced with the supervisory style of the cooperating teachers.

Frequent Communication. Frequent communication with cooperating teachers was viewed as important in order to gain a clearer picture of the relationship with the student teacher and to more accurately gauge improvement of the student teacher. Jamie, Secondary CS, explained:

As a college supervisor a lot of times we are sort of on the outside looking in and I think the daily journals, the email that we get everyday from the student teachers has really helped bring us into the scene a little bit more if you will and I think to expand that communication with the cooperating teachers will sort of complete that picture where we will have a better understanding from both the teacher's perspective and the student's perspective. 
Increased communication between cooperating teachers and college supervisors was viewed as an avenue to enhance the student teaching experience.

Expectations. College supervisors also stated that they would clearly review expectations for cooperating teachers who were in situations where they did not feel that the relationship was as conducive for student teachers as it could have been. Regan, Secondary CS, explained a change that was implemented after supervising a student teacher who was assigned to a cooperating teacher who demonstrated supervisory practices that were perceived as adversarial by the college supervisor. Regan, Secondary CS, stated : "I sit down with them and I have a meeting with them and I clearly define the expectations for what I expect to see from them." Kendal, Elementary CS, agreed stating: "I make sure that I outlined everything at the beginning."

\section{Expectations}

In contrast to the opinions of the student teachers and cooperating teachers, college supervisors were in agreement that their expectations of student teachers were complementary to the expectations of cooperating teachers.

Complementary. Aran, Elementary CS, stated: "You know, we seem to really agree." Kendal, Secondary CS, stated: "Yes, I think we are right on the same page." Even though college supervisors visited an average of three occasions, the view was that expectations were the same between college supervisors and cooperating teachers. This was due to familiarity with requirements of the educator licensure program.

\section{Communication}

College supervisors stated that overall they felt that they had good relationships with student teachers even though it was mainly based through email.

Informal. The success of the relationship by college supervisors was based on the perception of openness and honesty expressed in emails by student teachers. Dayna, Secondary CS, stated: "(Name of student teacher) shares a lot in her journals with me and I share a fair amount back and I think the relationship has mainly been positive." When student teachers appeared to be open and honest in their journals, college supervisors viewed that as a sign of a good relationship.

\section{Supervisory Model}

Similarly to the views of the cooperating teachers, all college supervisors expressed the importance of having two supervisors for student teachers.

Enhancement. College supervisors expressed the importance of complementary views that two supervisors could offer. Dayna, Secondary CS, stated: "Well I think two people, one person would see something that another person wouldn't see and make a suggestion." College supervisors were in agreement that two supervisors assisting in enhancing the experience of the student teacher.

\section{Limitations}

When interpreting the results of the current study, a few limitations should be considered. All participants were from the same educator licensure program and the sample size was relatively small. This does not allow for generalizations to be made to larger programs. All supervisors were very familiar with the program, which allowed for certain assumptions to be made by them. Observation was not used due to the geographical distance between the research and participants. Results are limited to the honesty in responses of participants.

\section{Discussion}

The results revealed important findings in terms of the implications regarding perceptions of relationships formed among members of the student teaching triad and implications regarding perceptions of supervision of student teachers given by cooperating teachers and college supervisors. The results of the current study are consistent with findings in pedagogical research. Discussion has been presented combining placement (elementary and secondary) and according to role (student teacher [ST], cooperating teachers $[\mathrm{CT}]$ and college supervisor $[\mathrm{CS}]$.

\section{Student Teachers}

Student teachers in the current study all agreed that expectations of college supervisors are based on theory whereas those of cooperating teachers are based on what was practical and what worked best for the students. This finding is similar to the findings of DelGesso and Smith (1993) and Richardson-Koehler (1998) who also stated that often times, advice and suggestions from college supervisors 
is based on theory and advice from cooperating teachers is more from a pragmatic view. This is due to the fact that cooperating teachers are more familiar with contextual factors that affect student learning compared to college supervisors who may not be as familiar. Also, cooperating teachers are able to develop more realistic views of the performance and achievement of student teachers due to the daily contact. This is also in agreement with Gallemore (1981) and Moon et al. (1988) who stated that a difference does exist in the perceptions of achievement by the student teacher, the cooperating teacher, and the college supervisor.

Professional growth for student teachers is based on feedback received from cooperating teachers, amount of structure given by cooperating teachers and college supervisors to student teachers, and personal connections developed between cooperating teachers and student teachers. Student teachers desire to learn and gain the most from their experience. When cooperating teachers are able to add constructive criticism, the experience is viewed as successful from student teachers. Structure and clear expectations are also expressed as important by student teachers. Student teachers feel the need to be aware of all expectations by cooperating teachers and college supervisors in order to meet them. Student teachers place an importance on developing personal relationships with cooperating teachers. When the relationship is relaxed and comfortable, they are able to learn more, worry less, and take more chances. This finding is in agreement with Veal and Rikard (1998) who stated that a majority of the time, the coalition is formed between the student teacher and the cooperating teacher due to the amount of time spent together on a daily basis. As a result, this relationship is viewed as the most important.

Finally, there is a difference in amount of communication among student teachers, cooperating teachers, and college supervisors. Communication with college supervisors is informal and mainly based through emails, telephone conversations, and daily journals whereas communication with cooperating teachers is daily. This has an affect on the type of relationship formed between the student teacher and the cooperating teachers and the supervisory style used by the cooperating teachers. This is in agreement with Veal and Rikard (1998) who stated that the cooperating teachers do spend more time with the student teacher. Moon et al. (1988) who stated that perceptions formed by cooperating teachers and college supervisors are different.

\section{Cooperating Teachers}

Cooperating teachers all state that training is not received concerning the supervision of student teachers. This finding is in agreement with many researchers who stated that lack of clear guidelines given to cooperating teachers regarding supervision and expectations of student teachers is a dominant area of concern (Grimmett \& Ratzlaff, 1986; Koerner, 1992; RichardonsKoehler, 1998; Rikard \& Veal, 1996). The findings of the current researcher add support to the findings of Grimmett and Ratzlaff (1986) who stated "that the role of the cooperating is poorly defined and that teachers generally are unprepared for the task of student teaching supervision" (p. 42). Koerner (1992), Richardson-Koehler (1988), and Rikard and Veal (1996) found that supervision of cooperating teachers is guided by past personal experiences in student teaching and current professional practices. Cooperating teachers in the current study do support these findings by stating that personal styles are changed and modified consistently according to what is most beneficial for student teachers along with what has been taught to them during their student teaching experience.

Cooperating teachers place an importance of the professional growth of student teachers by the establishment of personal relationships. When student teachers establish close relationships with cooperating teachers, they are able to gain trust not only in themselves but in their ability to become competent, effective teachers. This finding is in agreement with Rikard and Veal (1996) who stated that not only are cooperating teachers the very influential for student teachers, but "the nature and quality of that influence seem to be critical factors in determining student teacher development." (p. 279). This tendency can also be explained by the triad theory (Caplow, 1968). Because student teachers and cooperating teachers spend the majority of time together, a greater appreciation and empathy is allowed to develop (Rikard \& Veal, 1998). This is apparent in the current study.

Cooperating teachers also view having a student teacher as beneficial for their own professional growth in terms of the new ideas that student teachers can introduce to them. Often time, student teachers do have new, innovative ideas to bring to the student teaching setting.

Cooperating teachers have higher expectations in terms of achievement of the student teachers compared to college supervisors. This is in agreement to the findings 
of Gallemore (1981) and Moon et al. (1988) who found that perceptions of achievement by cooperating teachers and college supervisors are different. The differences in the current study were due to the amount of time cooperating teachers spend with student teachers compared to college supervisors. Cooperating teachers are able to more realistically gauge the improvement of student teachers due to observation of daily performance on a daily basis.

Cooperating teachers all agree that the supervisory model of two supervisors is most conductive to the professional development and enhancement of the overall experience of student teachers. The general consensus is that this model allows for complementary feedback and different viewpoints. If supervisors do not agree then such a model would be contradictory, but in this situation, this model is the best. When two supervisors observe a student teacher, each will have different observations. This allows for the most learning to occur for student teachers. Communication with college supervisors in the current study is informal and infrequent. College supervisors are asked to make three observations in the 7-week period and communicate mainly by telephone and email. This type of infrequent and informal communication allows for student teachers to have the opportunity to develop stronger and closer relationships with cooperating teachers.

\section{College Supervisors}

College supervisors also state that training is not received concerning the supervision of student teachers. Supervision of student teachers is based on a combination of past teaching experience as physical educators, past experience as cooperating teachers, and past administrative experience. Koerner (1992), Richardson-Koehler (1988), and Rikard and Veal (1996) conducted research utilizing the socialization theory proposed by Lortie (1975) that supported this finding. The premise behind the socialization theory (Lortie, 1975) is the combination of past personal life experiences and current practical experience (Rikard \& Veal, 1996). Based on past experiences, college supervisors are able to cite examples to assist student teachers in becoming effective teachers. Supervising student teachers in the current educator licensure program also assists in informing college supervisors of current issues in teaching which adds to their experience and what they continue to offer student teachers.
Such a finding is in contrast to DelGesso and Smith (1993) and Richardson-Koehler (1998) who found that supervision practices among college supervisors is mainly based on college protocol and theory. The connection to college protocol and theory is evident among college supervisors in the current study. College supervisors place more of an emphasis on assessments and standard-based teaching which is currently the emphasis in educator licensure programs; however, past experiences do assist to add to realistic examples to offer student teachers.

A new finding in the current study is the suggestion of increased communication between college supervisors and cooperating teachers. College supervisors state that this will be a change that they will implement to assist in completing the picture of the development and daily struggles of student teachers. This will also allow for a more realistic view of the perception of achievement of student teachers. If directors of placement in educator licensure program place a large amount of student teachers in placement at practicum sites each semester, it may be that the assigned college supervisor has not had the prior opportunity to have had the assigned student teacher in classes and is therefore unfamiliar with that student teacher. Then the perception of the college supervisor in this situation is developed solely in the student teaching environment. Increased communication with cooperating teachers will allow for a more realistic view to occur.

An interesting finding in the current study involves the difference in perceptions of expectations among college supervisors and cooperating teachers. This finding is in agreement with Gallemore (1981) and Moon et al. (1988) who found that a difference in perceptions does occur; however, in the current study, cooperating teachers feel that their expectations are higher and college supervisors state that their expectations are complementary. This may be due to the fact that all supervisors are alumni, currently teaching, or familiar with the requirements of the current licensure program. This allows for a consistency in terms of observations and completing evaluation forms. College supervisors may feel that views are complementary due to similar comments given by both college supervisors and cooperating teachers on evaluation forms. College supervisors in the current study also agree with cooperating teachers that the supervisory model of two supervisors allows for enhancement of professional development of student teachers. 


\section{Conclusions and Implications}

The findings of the current study emphasize the importance of perceptions regarding relationships that are formed among members of the student teaching triad along with perceptions of supervision of student teachers given by cooperating teachers and college supervisors. Many student teachers are placed at sites due to convenience. Relationships formed between cooperating teachers and student teachers can have a profound affect on the professional development of student teachers (Veal \& Rikard, 1998). It is critical to for directors of placement in educator licensure programs to invest time to find the most compatible placements for student teachers. This is not always possible due to many factors. Supervisors of student teachers do need to receive some type of training regarding expectations and guidelines. This was not an issue in the current study due to the familiarity of requirements and of the program by all supervisors; however, all supervisors did state that formal training was not received.

Increasing communication with cooperating teachers and college supervisors is critical to allow for a more realistic view of achievement and success of student teachers. Clear expectations of cooperating teachers stated prior to the beginning of the experience will assist in alleviating conflict that could occur among student teachers, cooperating teachers, and college supervisors.

Research investing differences in training received by cooperating teachers and college supervisors is critical. In the current study, cooperating teachers and college supervisors all stated that the supervision of student teachers was based on past experience and current teaching experience. Continuing research in this area will emphasize the need for implementation of training programs for supervisors in educator licensure programs.

Research involving the investigation of preferred supervisory styles should continue. Participants in the current study involved student teachers placed at one placement. Examining student teachers placed at both elementary and secondary placements for the entire student teaching experience would aid in a more in-depth understanding of the growth in teaching of student teachers and the stability of the relationship between college supervisors and student teachers. Such studies would also add insight into the changes in supervisory styles from one placement to the next.

\section{References}

Caplow, T. (1968). To against one: Coalitions in triads. Englewood Cliffs, NJ: Prentice Hall.

Copeland, W. D. (1982, March-April). Student teachers' preference for supervisory approach. Journal of Teacher Education, 33(2), 32-36.

Delgesso, D. D., \& Smith, M. P. (1993, Fall). The undergraduate student teaching experience: Perspectives of student teachers, cooperating teacherss, and student teacher supervisors. Philadelphia, PA: Temple University. (ERIC Document Reproduction Service No. ED 368 710).

Gallemore, S. L. (1981). Perceptions about the objectives of student teaching. Research Quarterly for Exercise and Sport, 52(2), 180-190.

Glaser, B. G., \& Strauss, A. (1967). The discover of grounded theory: Strategies for qualitative research. Chicago, IL: Aldine.

Gould, D., Finch, L. M., \& Jackson, S. A. (1993). Coping strategies used by national champion figure skaters. Research Quarterly for Exercise and Sport, 64(4), 453-468.

Grimmett, P. P., \& Ratzlaff, H. C. (1986, NovemberDecember). Expectations for the cooperating teachers role. Journal of Teacher Education, 37, 41-48.

Housner, L. D., \& Griffey, D. C. (1985). Teacher cognition: Differences in planning and interactive decision making between experienced and inexperienced teachers. Research Quarterly for Exercise and Sport, 56(1), 45-53.

Koerner, M. E. (1992). The cooperating teachers: An ambivalent participant in student teaching. Journal of Teacher Education, 43(1), 46-56.

Lincoln, Y. S., \& Guba, E. G. (1985). Naturalistic inquiry. Newbury Park, CA: Sage.

Lortie, D. (1975). Schoolteacher: A sociological study. Chicago, IL: The University of Chicago Press. 
Lounsbery, M. F., \& Sharpe, T. (1999). Effects of sequential feedback on preservice teacher instructional interactions and students' skill practice. Journal of Teaching in Physical Education, 19, 58-78.

Marshall, C., \& Rossman, G. B. (1999). Designing qualitative research $\left(3^{\text {rd }}\right.$ ed.). Thousand Oaks, CA: Sage.

Maxwell, J. A. (1996). Qualitative research design: An interactive approach. Thousand Oaks, CA: Sage.

Moon, R. A., Niemeyer, R. C., \& Simmons, J. M. (1988, April 5-9). How well do the university supervisor, cooperating teachers, and the student teacher understand each other? Paper presented at the annual meeting of the American Educational Research Association, New Orleans, LA. (ERIC Document Reproduction Service No. ED 293 806)

Murphy, K. L. (2007). Perceptions of the student teaching triad: An inquiry into safe teaching practices of student teachers. Micronesian Educator, 12, 61-80.

Neuman, W. (1991). Social research methods. Boston, MA: Allyn and Bacon.

Practicum in Physical Education Fieldwork Handbook (2003-2004). [Brochure]. Springfield, MA. Author.

Richardson-Koehler, V. (1988, March-April). Barriers to the effective supervision of student teaching: A field study. Journal of Teacher Education, 39(2), 28-34.

Rikard, G. L., \& Veal, M. L. (1996). Cooperating teacherss: Insight into their preparation, beliefs, and practices. Journal of Teaching in Physical Education, 15, 279-296.

Seidman, I. (1998). Interviewing as qualitative research: A guide for researchers in education and the social sciences $\left(2^{\text {nd }}\right.$ ed.). New York: Teachers College Press.

Tan, S. K. S. (1996). Differences between experienced and inexperienced physical education teachers' augmented feedback and interactive teaching decisions. Journal of Teaching in Physical Education, 15, 151-170.
Thomas, J. R., Nelson, J. K., \& Silverman, S. J. (2005). Research methods in physical activity (5 $5^{\text {th }}$ ed.). Chicago, IL: Human Kinetics.

Tsangaridou, N., \& O'Sullivan, M. (1994). Using pedagogical reflective strategies to enhance reflection among preservice physical education teachers. Journal of Teaching in Physical Education, 14, 13-33.

Van der Smissen, B. (1990). Legal liability and risk management for public and private entities. Cincinnati, $\mathrm{OH}$ : Anderson.

Veal, M. L., \& Rikard, L. (1998, March-April). Cooperating teacherss' perspectives on the student teaching triad. Journal of Teacher Education, 49 (2), 108-119.

Vogt, M. E. (1988, May). The preservice teachercooperating teachers relationship: A historical perspective. Paper presented at the annual meeting of the International Reading Association, Toronto, Canada. (ERIC Document Reproduction Service No. ED 301 563).

Zeichner, K. (1992, September-October). Rethinking the practicum in the professional development school partnership. Journal of Teacher Education, 43(4), 296307.

\section{Correspondence:}

Kelle L. Murphy

Assistant Professor of Physical Education

School of Education, University of Guam

UOG Station, Mangilao, GU 96923

Telephone: (671) 735-2413

Fax: (671) 734-3651 